\title{
EVALUASI PELAKSANAAN CO-TEACHING BLENDED LEARNING BAHASA INGGRIS BIDANG KEWARGANEGARAAN
}

\author{
Hery Yanto The $1{ }^{*}$, Siti Awaliyah ${ }^{2}$ \\ ${ }^{1}$ Zhejiang Yuexiu University of Foreign Languages. 428 Huiji Rd, Yuecheng Qu, Shaoxing \\ Shi, Zhejiang Sheng, China, 312011. \\ 2 Universitas Negeri Malang. Jl. Semarang no. 5, Lowokwaru, Malang, Indonesia. \\ * Corresponding Author. Email: herythe@outlook.com \\ Received: 17 May 2018; Revised: 7 May 2019; Accepted: 9 May 2019
}

\begin{abstract}
Abstrak
Penelitian ini bertujuan memaparkan perancangan, pelaksanaan, dan evaluasi perkuliahan Bahasa Inggris Kewarganegaraan di Universitas Malang. Selain itu, penelitian ini juga menyajikan contoh lingkungan pembelajaran blended learning dengan menggunakan multimedia yang efektif untuk meningkatkan motivasi belajar mahasiswa di bidang Bahasa Inggris Kewarganegaraan. Pendekatan mixed-method digunakan untuk mengumpulkan, menyajikan, dan menganalisis data. Portofolio kegiatan instruksional dan kuisioner adalah bentuk data yang digunakan. Data disajikan dan dianalisis menggunakan narasi deskriptif, studi kasus, analisis dokumen, dan analisis statistik deskriptif. Hasil penelitian menunjukkan kolaborasi dalam bentuk co-teaching blended learning dapat meningkatkan kualitas pembelajaran. Kedua instruktur yang terlibat dalam kolaborasi dapat saling mendukung untuk mencapai tujuan pembelajaran. Selain diperlukan keahlian di dalam mengajar, instruktur juga perlu menguasai cara perancangan instruksional. Mahasiswa secara aktif bekerja secara berpasangan, berdiskusi, dan berkelompok di dalam menyelesaikan tugas pembelajaran di dalam kelas dan di Edmodo. Interaksi mahasiswa dengan materi belajar dan instruktur juga dapat difasilitasi dengan manajemen sistem belajar dan teknologi pembelajaran daring seperti VoiceThread, Skype, VSee, dan posel.
\end{abstract}

Kata kunci: Blended learning, pembelajaran multimedia

\section{EVALUATING THE IMPLEMENTATION OF CO-TEACHING BLENDED LEARNING THE ENGLISH FOR SPECIFIC PURPOSES IN CIVIC EDUCATION PROGRAM}

\section{Abstract}

This study reveals the design, implementation, and evaluation of the English for Specific Purposes Course in Civic Education Program at the State University of Malang. The course multimedia learning environment was designed based on the blended learning principals. This learning environment is effective to increase students' motivation. The study applied mixed-method approaches to collect, present, and analyze data. The instructional portfolio and a questionnaire were used as data. The narrative descriptive, case study, document analysis, and descriptive statistics principals were applied to analyze and present data. The results showed that co-teaching in the form of blended learning can improve the quality of the course and students' learning. Instructors can support one another collaboratively to achieve the learning objectives. Besides teaching skills, the instructors should acquire sufficient instructional design skills. Students were identified actively engaging in pair works, discussions, and groups' works to complete their learning tasks in class and in Edmodo. Interactions are mediated sufficiently by the learning management system and learning technologies, such as VoiceThread, Skype, VSee, and email.

Keywords: Blended learning, multimedia learning

doi http://dx.doi.org/10.21831/jitp.v6.1.19701 


\section{Pendahuluan}

Melalui pengalaman dan juga evaluasi diri, instruktur di perguruan tinggi dapat mengetahui kekurangan dirinya dalam menjalankan tugas mengajar (Liu \& Sayer, 2016, p. 3). Salah satu kekurangan tersebut adalah ketika instruktur diberi tugas oleh kampus untuk mengampu mata kuliah yang tidak langsung berhubungan erat dengan bidang keahliannya. Untuk mengatasi kekurangan tersebut, instruktur dapat membentuk tim pengajaran (team teaching) atau melakukan pengajaran bersama dengan instruktur lain (co-teaching). Tim pengajaran dan co-teaching dapat dilaksanakan dengan kolaborasi antar-instruktur dan telah terbukti dapat meningkatkan kualitas pengajaran (Hanusch, Obijiofor \& Volcic, 2009, p. 72; Stark, 2015, p. 7).

Pada penelitian ini co-teaching merupakan alternatif yang dipilih oleh dua instruktur mata kuliah berbentuk blended learning, Bahasa Inggris Kewarganegaraan (BIK) di Universitas Negeri Malang (UM). Co-teaching memungkinkan kedua instruktur untuk saling melengkapi dalam memandu kegiatan instruksional (Hamdan, Anuar, \& Khan, 2016, p. 289). Dalam pelaksanaannya, instruktur berbagi tugas secara seimbang, saling melengkapi, dan saling menyempurnakan keahlian satu sama lain (Texas Education Agency, 2010, p. 23). Porsi tugas yang seimbang disepakati bersama dan dijalankan dengan komitmen mulai dari perancangan dan pelaksanaan instruksional sampai dengan evaluasi (Friend, 2016, pp. 11-12).

Kedua instruktur memiliki keahlian dan pengalaman akademik yang berbedabeda. Instruktur utama, penanggungjawab mata kuliah, memiliki latar belakang keahlian di bidang Ilmu Hukum dan Pendidikan Kewarganegaraan, sedangkan instruktur tamu berlatar belakang keahlian di bidang Perancangan Instruksional Teknologi dan Pembelajaran Bahasa Asing. Pengalaman yang dimiliki oleh instruktur utama adalah merancang dan mengajar di Indonesia dengan menggunakan kurikulum dan sis- tem pendidikan Indonesia. Sementara, instruktur tamu mengajar dan merancang kegiatan instruksional di Indonesia, Amerika Serikat, dan di Tiongkok. Instruktur utama hadir di dalam kelas, sedangkan instruktur tamu melakukan video konferensi dari tempat tinggalnya di Honolulu, Amerika Serikat.

Sesuai dengan ketentuan kampus, pengajaran bahasa Inggris sebagai mata kuliah wajib jurusan disesuaikan dengan bidang keilmuan yang dipelajari oleh mahasiswa. Khusus untuk program studi S1 Pendidikan Pancasila dan Kewarganegaraan (PPKn), pengajaran bahasa Inggris harus mengandung muatan bidang keahlian hukum dan kewarganegaraan. Mata kuliah ini diberi nama Bahasa Inggris Kewarganegaraan (BIK). BIK memiliki bobot 2 Satuan Kredit Semester (SKS) dan wajib ditempuh oleh mahasiswa tahun pertama di semester kedua. Dalam kuliah BIK, mahasiswa perlu mendapatkan pengalaman belajar langsung untuk menerapkan aspek kebahasaan dalam komunikasi ilmiah dibidang keilmuannya.

Pada tahap analisis kebutuhan, kedua instruktur mengidentifikasi kekurangan pelaksanaan instruksional BIK pada semester-semester sebelumnya. Salah satu dari kekurangan tersebut adalah perkuliahan yang kurang menarik karena terlalu didominasi oleh kegiatan membaca artikel ilmiah, menerjemahkan artikel, dan kegiatan menghafal kosa kata. Penggunaan multimedia dan sarana belajar selain buku teks pelajaran juga sangat rendah intensitasnya. Analisis kebutuhan menunjukkan kekurangan tersebut dapat diselesaikan dengan menerapkan rancangan pembelajaran co-teaching secara blended learning.

Kegiatan perkuliahan yang seharusnya dilakukan hanya dengan pertemuan kelas diubah oleh kedua instruktur menjadi kuliah yang memadukan pertemuan kelas, telekonferensi, dan penyelesaian tugas dihalaman manajemen sistem pembelajaran, Edmodo. Seluruh pertemuan kelas sebanyak 14 pertemuan dalam satu semester menghadirkan instruktur tamu ke dalam 
kelas melalui video konferensi Skype atau VSee. Selain itu, mahasiswa juga diwajibkan untuk melakukan diskusi dan interaksi dengan instruktur tamu menggunakan Edmodo dan posel.

Penelitian ini memaparkan proses perancangan, pelaksanaan, dan evaluasi perkuliahan BIK selama satu semester di program studi S1 PPKn, Universitas Negeri Malang (UM). Lingkungan belajar blended learning mengintegrasikan teknologi multimedia untuk meningkatkan motivasi belajar mahasiswa terhadap mata kuliah BIK. Hasil penelitian ini merupakan sebuah contoh untuk pengembangan dan pelaksanaan co-teaching blended learning baik di lingkugan kampus UM maupun kampus-kampus lainnya di Indonesia. Penelitian ini juga menyajikan evaluasi mahasiswa terhadap kualitas instruksional dan kualitas belajar.

Hasil penelitian ini dianalisis menggunakan pendekatan interdisipliner, yaitu dengan memadukan pendekatan ekologi perancangan lingkungan belajar dengan analisis nilai dan daya guna mutimedia yang tersedia pada lingkungan belajar. Selain itu, karena BIK merupakan mata kuliah blended learning bahasa asing, maka evaluasi perancangan sampai dengan hasil pelaksanaannya menggunakan pendekatan pembelajaran bahasa secara komunikatif yang dipadukan dengan prinsip perancangan instruksional dan model pembelajaran blended learning.

Mengacu pada pedekatan ekologi yang dikembangkan oleh Bronfenbrenner (1979) dan Gibson (1979), lingkungan belajar dapat dilihat sebagai sebuah sistem yang memiliki atribut-atribut alamiah dan atribut-atribut buatan yang dapat digunakan pembelajar untuk mendukung proses belajar dan pencapaian tujuan belajar (Barnett, 2011, p. 141; Yang, 2018, p. 27). Suhu ruangan, contohnya, merupakan atribut alamiah. Ruang kelas dan kipas angin adalah contoh atribut yang dapat membuat tempat belajar menjadi nyaman untuk belajar. Teknologi yang tersedia di sekitar mahasiswa dapat difungsikan secara optimal sebagai atribut-atribut buatan yang dapat memperlancar serta mendukung proses belajar dan pencapaian hasil belajar (Klopfer et al., 2009, p. 3).

Atribut-atribut pada lingkungan belajar dapat ditambahkan, dikeluarkan, dan dimodifikasi untuk mempermudah pembelajar menemukan nilai dan daya gunanya (Okeke, 2013, p. 101). Meja, kursi, dan whiteboard misal-nya, merupakan atribut yang bisa dengan mudah diubah dan diatur posisinya sesuai dengan keperluan aktivitas di kelas (Okeke, 2013, p. 101). Teknologi multimedia dapat dipasang atau dibawa ke dalam kelas untuk mempermudah pelaksanaan aktivitas belajar (Klopfer et al., 2009, p. 3; Umeh \& Nsofor, 2014, pp. 74-77). Jika lingkungan belajar internal tidak memungkinkan untuk menambahkan atribut luar, maka lingkungan eksternal dapat digunakan sebagai pengganti dan/atau pelengkap untuk mendukung pencapaian hasil belajar (KemalRamani et al., 2018: pp. 5-35). Kampus dan kelas merupakan contoh lingkungan internal, sedangkan alam sekitar, tempat kerja praktik, dan laman belajar di internet merupakan contoh lingkungan eksternal (Sheerman et al., 2010, pp. 9-10).

Lingkungan belajar merupakan sistem yang terbuka, sehingga interaksi antara lingkungan belajar dengan lingkungan lain akan selalu terjadi (Bronfenbrenner, 1994, p. 39-41; Harkonen, 2007, p. 7-14). Interaksi dan komunikasi dalam proses belajar bertujuan untuk menyampaikan dan bertukar idea. Interaksi dan komunikasi dapat terjadi antara pembelajar dengan pembelajar, pembelajar dengan atribut belajar, pembelajar dengan instruktur, dan pembelajar dengan pihak-pihak lain di luar lingkungan internal (Moore, 2009, pp. 1-7). Interaksi dan komunikasi dapat terjadi secara langsung antara pembelajar dengan mitra komunikasi (human-human interaction and communication) atau terjadi melalui fasilitasi media/teknologi (technology mediated interaction and communication).

Mengacu pada pendekatan komunikatif belajar bahasa (Ju, 2001, p. 1581; Klapper, 2006, p. 109; Candlin \& Mercer, 2001, p. 155 ), komunikasi ide di dalam 
proses belajar berpusat pada kegiatan pembelajar (student center). Menurut Vygotsky (1967, p. 16), instruktur sebagai agen perubahan berperan penting dalam menuntun pembelajar untuk melampaui zone of proximal develop-ment (ZPD), tahap di mana bimbingan dan arahan diperlukan sebelum pembelajar mampu belajar dan bekerja secara mandiri. Instruktur menjadi fasilitator dan mediator interaksi dan komunikasi (Basta, 2011, p. 132). Bimbingan dan arahan (instructional scaffolding) dapat dilakukan dengan mem-berikan instruksi yang jelas, konfirmasi instruksi, dan memberikan contoh dan bukan contoh dari hasil belajar yang di-harapkan (Rosenshine \& Meister, 1992, p. 27).

Pembelajaran bahasa dengan pendekatan komunikatif dapat dilaksanakan dengan kerja berpasangan, kerja kelompok, bermain peran, diskusi, kolaborasi dalam penyelesaian masalah, diskusi, debat, dan permainan (Drothler, 2002, pp. 1-6). Caracara pembelajar seperti ini semakin mudah di-laksanakan dengan adanya teknologi digit-al dan multimedia yang memungkinkan komunikasi dan interaksi diperluas tanpa adanya batasan pada ruang dan waktu (Shyamlee \& Phil, 2012, pp. 150-151). Sistem manajemen belajar merupakan sebuah inovasi dibidang teknologi pendidikan yang memungkinkan pembelajar meman-faatkan lingkungan belajar daring untuk berinteraksi dan berkomunikasi dengan pembelajar lain dan instruktur (Adzharuddin \& Ling, 2013, p. 48; Sejzi \& Aris, 2013, p. 217). Ketika sistem daring ini dipadukan dan diintegrasikan ke dalam pertemuan kelas dihasilkanlah pembelajaran blended learning.

Blended learning yang berkualitas membantu pembelajar memperoleh keterampilan yang diperlukannya setelah menempuh proses belajar. Pelaksanaan blended learning bukan hanya sebatas mengintegrasikan teknologi ke dalam kegiatan belajar atau membawa teknologi ke dalam kelas, namun blended learning memadukan pembelajaran kelas dengan teknologi dan lingkungan belajar daring untuk memper- mudah pencapaian tujuan belajar (Garrison \& Kanuka, 2004, p. 97). Pelaksanaan blended learning harus didasarkan pada analisis kebutuhan sampai dengan pelaksanaan kegiatan belajar sesuai dengan prinsipprinsip perancangan instruksional pembelajaran (El-Mowafy, Kuhn \& Snow, 2013, pp. 134-137).

Ada berbagai model perancangan instruksional dan dalam perancangan mata kuliah BIK, kedua instruktur menerapkan model sistem perancangan instruksional yang dikembangkan oleh Dick, Carey dan Carey (2014, p. 6-8). Model ini menerapkan sistem backward design, di mana instruktur terlebih dahulu menetapkan tujuan-tujuan instruksional yang disertai dengan penyusunan instrumen evaluasi, kemudian menguji coba instrument tersebut dan melakukan analisis kebutuhan (Dick, Carey \& Carey, 2014, p. 16-24). Selanjutnya instruktur mengembangkan modul, strategi instruksional, serta menetapkan teknologi pendukung instruksional (Dick, Carey \& Carey, 2014, p. 25-29). Model ini memungkinkan modifikasi instruksional ketika dalam proses ditemukan ketidaksesuaian antara rencana awal dengan kemampuan pembelajar dalam mendayagunakan atribut-atribut lingkungan belajar yang telah disiapkan (The Herridge Group, 2004, p. 12).

\section{Metode Penelitian}

Penelitian ini berbentuk mix-methods (Creswell, 2014) mencakup jenis naratif deskriptif, studi kasus, analisis dokumen, dan analisis statistik deskriptif. Naratif deskriptif dan studi kasus digunakan untuk memaparkan kegiatan perancangan instruksional dan pelaksanaannya berdasarkan hasil pengamatan dan dokumentasi peneliti. Analisis dokumen digunakan untuk menunjukkan hasil-hasil rancangan dan pelaksanaan evaluasi kegiatan maha-siswa dan evaluasi penggunaan media, serta pelaksanaan perancangan lingkungan pembelajaran untuk memenuhi kebutuhan pelaksanaan blended learning. Analisis statistik deskriptif digunakan untuk menyajikan 
dan menganalisis hasil belajar mahasiswa dan evaluasi mahasiswa terhadap mata kuliah.

Data untuk penelitian ini terdiri atas catatan hasil pengamatan instruktur terhadap kegiatan yang ada di dalam kelas, catatan pengamatan kegiatan mahasiswa di Edmodo, serta ponsel yang digunakan sebagai media komunikasi antara instruktur dengan instruktur dan antara instruktur dengan mahasiswa. Selain itu dokumen yang dihasilkan dari proses perancangan instruksional dan evaluasi hasil belajar yang merupakan portofolio administrasi kegiatan perkuliah juga ditelusuri untuk memperoleh informasi mengenai perancangan sampai dengan evaluasi. Kutipan dari portofolio tugas mahasiswa merupakan informasi penting yang dapat dijadikan sebagai sumber data mengenai kegiatan instruksional dan proses evaluasi. Kuisioner semi tertutup yang diisi oleh mahasiswa juga turut diikutsertakan sebagai data dalam penelitian ini.

Data dikumpulkan selama satu semester perkuliahan pada tahun akademik 2014/2015. Data berbentuk dokumen dan portofolio dikumpulkan dengan teknik penelusuran dan analisis dokumen. Data yang diperlukan dikutip dari sumber dan dijadikan contoh untuk pembahasan hasil penelitian. Kuisioner dikumpulkan dengan menggunakan sampel populasi dan 82 mahasiswa mengisi kuisioner yang terdiri dari 20 pertanyaan tertutup dan 5 pertanyaan terbuka setelah mereka menyelesaikan ujian akhir semester. Untuk keperluan analisis pada penelitian ini, digunakan 5 item pertanyaan tertutup pada kusioner tersebut.

Data mengenai kegiatan perkuliahan dan strategi instruksional disajikan secara naratif dengan menggunakan contoh untuk memperjelas deskripsi. Penggunaan multimedia dan evaluasi proses belajar, dijelaskan dengan deskripsi yang didukung dengan contoh hasil kegiatan mahasiswa. Evaluasi hasil akhir belajar mahasiswa dan evaluasi mahasiswa terhadap mata kuliah ditampilkan dengan tabel yang disertai dengan penjelasan kecenderungan data menggunakan pendekatan statistik deskripsi.

\section{Hasil dan Pembahasan}

Hasil penelitian disajikan dalam lima bagian dan dilanjutkan dengan analisis. Bagian pertama dibahas kegiatan perkuliahan. Bagian kedua memaparkan strategi instruksional dan dilanjutkan dengan penjelasan mengenai penggunaan media pada bagian ketiga. Portofolio hasil belajar disajikan sebelum deskripsi statistik nilai akhir mahasiswa dan evaluasi mahasiswa terhadap perkuliahan.

\section{Kegiatan Perkuliahan}

Uji coba telekonferensi dengan aplikasi Skype atau VSee dilakukan antara satu atau dua jam sebelum perkuliahan berlangsung. Pada saat uji coba, kedua instruktur mendiskusikan kegiatan-kegiatan pengganti jika pada saat perkuliahan sambungan internet terputus. Pada saat kegiatan perkuliahan berlangsung, instruktur tamu memberikan penjelasan dan arahan lewat telekonferensi, sedangkan instruktur utama memberikan penjelasan tambahan dan mengawasi pelaksanaan kegiatan. Pertanyaan dan penjelasan tambahan dapat diajukan kepada kedua instruktur pada saat perkuliahan dan jika diperlukan penjelasan tambahan, mahasiswa dapat menghubungi instruktur melalui posel dan forum diskusi.

Forum diskusi disediakan secara daring di Edmodo. Mahasiswa diwajibkan mengunjungi Edmodo minimal satu jam setiap minggu. Bahan-bahan pendukung proses belajar, seperti modul belajar dan petunjuk penyelesaian tugas juga disediakan pada Edmodo dalam bentuk berkas elektronik. Mahasiswa juga diberikan kewajiban untuk mengumpulkan tugas-tugas kuliah dalam bentuk berkas elektronik melalui fitur pengumpulan tugas pada Edmodo.

Pada saat kuliah di kelas, mahasiswa dibimbing untuk menyelesaikan tugas menggunakan media yang tersedia di 
kelas (seperti papan tulis, karton manila, peralatan tulis, permainan berbentuk kartu) dan media daring (seperti iM-Translator, Google Translate, kamus elektronik, dan berbagai permainan da-ring). Kegiatan kelas dan tugas-tugas kuliah diselesaikan secara berpasangan atau berkelompok. Posisi duduk mahasiswa di dalam kelas juga disesuaikan dengan kegiatan yang dilaksanakan. Kadang maha-siswa duduk secara melingkar, duduk dalam posisi berbentuk U, duduk berhadapan dengan pasangan kerjanya, atau duduk saling berhadapan antar kelompok. Selain duduk, mahasiswa juga diberi kegiatan yang mengharuskan mereka berdiri dan bergerak dari satu posisi ke posisi lain di dalam kelas.

Keluaran yang diwajibkan kepada mahasiswa terdiri atas flash cards, menulis kalimat, membuat rekaman berbicara, dan menulis paragraf ringkasan video TedTalk. Keluaran tersebut dievaluasi sebagai portofolio hasil kegiatan belajar dan diberi bobot $50 \%$ dari jumlah seluruh nilai akhir. Selain portofolio, nilai akhir juga dapat diperoleh mahasiswa dari kegiatan partisipasi dalam bentuk tanya-jawab di kelas atau di Edmodo (20\%), Ujian Tengah Semester (10\%), dan Ujian Akhir Semester (20\%).

\section{Strategi Instruksional}

Sebelum menghadiri perkuliahan di kelas, mahasiswa diberi tugas membaca petunjuk pelaksanaan kegiatan di kelas melalui modul yang diposting pada laman Edmodo. Pada saat perkuliahan, instruktur tamu menjelaskan aspek-aspek kebahasaan dan memberikan contoh-contoh hasil yang diharapkan dari kegiatan. Instruktur utama kemudian membimbing dan mengatur pelaksanaan kegiatan. Pertanyaan dapat diajukan mahasiswa setelah instruktur tamu menjelaskan atau pada saat ditemukan hambatan ketika sedang menyelesaikan kegiatan. Instruktur tamu memberikan arahan dengan cara menjawab langsung melalui video konferensi atau menuliskan jawaban pada ruang chat yang tersedia pada Skype dan VSee.
Pada setiap perkuliahan terdapat tugas yang harus diselesaikan dan kegiatan ini dirancang dengan tujuan memberikan pengalaman belajar langsung kepada mahasiswa. Mahasiswa menggunakan media di kelas dan media daring untuk menyelesaikan tugas tersebut. Sebagai contoh, mahasiswa menggunakan iM-Translator atau kamus eletronik untuk mendengarkan pengujaran kata-kata dan kemudian secara berpasangan berlatih mengujarkan dan mengoreksi kesalahan pasangannya. Mahasiswa juga berlatih memperbaiki kekeliruan penerjemahan yang dilakukan oleh Google Translate.

\section{Penggunaan Multimedia}

Pemilihan dan penggunaan multimedia disesuaikan dengan keperluan praktik dan tujuan pembelajaran. Teknologi tersebut terdiri atas teknologi daring dan luring. Media luring yang digunakan terdiri atas komputer kampus yang tidak terhubung ke internet, mesin perekam suara, kamera, dan telepon seluler tanpa koneksi internet. Peralatan ini digunakan oleh mahasiswa ketika mereka menyelesaikan tugas di luar kelas untuk melengkapi portofolio. Sedangkan media daring terdiri dari laptop dan iPad yang terhubung ke internet, aplikasi-aplikasi belajar bahasa di komputer dan telepon seluler, aplikasi telekonferensi, Edmodo, dan video-video yang tersedia di Internet.

Skype dan Vsee digunakan untuk melakukan telekonferensi. Instruktur utama akan melakukan dua sambungan telekonferensi dengan instruktur tamu. Sambungan pertama dilakukan dengan laptop di dalam kelas dan panggilan lain menggunakan iPad. Panggilan menggunakan laptop ditayangkan pada dinding kelas, sedangkan panggilan iPad digunakan sebagai media chatting untuk koordinasi antarinstruktur selama proses perkuliahan. Aplikasi Skype digunakan jika pembelajaran tidak memerlukan penyajian media daring secara langsung dari layar laptop instruktur tamu. VSee digunakan jika instuktur tamu 
perlu melakukan penyajian media atau laman-laman internet melalui laptopnya yang kemudian diproyeksikan di kelas. Penggunaan kedua media telekonferensi juga sebagai alternatif untuk dapat terus berkoordinasi selama proses perkuliahan jika hubungan internet ke salah satu media terganggu, misalnya jaringan terputus.

VoiceThread merupakan aplikasi perekam suara yang digunakan di dalam mata kuliah ini sebagai media pendukung perkenalan diri antara mahasiswa dengan instruktur. Kedua instruktur memberikan contoh dengan melakukan posting pengenalan diri dan mahasiswa diberi tugas untuk melakukan posting dengan cara yang sama. Dua pilihan diberikan kepada mahasiswa untuk melakukan posting perkenalan dirinya pada VoiceThread. Jika mahasiswa merasa yakin dapat mengintegrasikan audio dan video, maka mereka dapat memposting video, sedangkan bagi yang merasa kurang yakin dengan kemampuan menggunakan fitur video pada aplikasi VoiceThread, mereka cukup memposting audio. Langkah-langkah dalam menggunakan fitur-fitur tersebut diberikan dalam modul perkuliahan dan diposting di Edmodo.

Video presentasi pada TedTalk dijadikan sebagai contoh dan tugas membuat ringkasan. Pertama-tama, dalam kegiatan di kelas, instruktur menayangkan sebuah video TedTalk dan mahasiswa menyaksikan video tersebut. Kemudian, instruktur menyajikan 3 contoh ringkasan sepanjang 100-150 kata dari video tersebut. Mahasiswa kemudian dikelompokkan antara 4-6 orang dan ditugaskan untuk membuat ringkasan dari video TedTalk yang lain. Setiap kelompok ditugaskan menonton video yang berbeda. Hasil ringkasan dikirimkan kepada instruktur tamu untuk disempurnakan sebelum dipresentasikan di kelas.

Latihan kosa kata diberikan melalui fitur kuis pada laman Edmodo. Mahasiswa secara individu diberi waktu untuk menyelesaikan kuis-kuis yang ditugaskan. Fitur kuis pada Edmodo memungkinkan instruk- tur merancang bebagai bentuk jenis pertanyaan, seperti pilihan ganda, benar-salah, menjodohkan, isian singkat, dan jawaban panjang. Namun, mengingat mahasiswa telah memiliki beban tugas yang cukup banyak, jenis pertanyaan yang diberikan hanya dibatasi pada pilihan ganda. Tujuan utama penugasan kuis ini adalah memberikan kesempatan kepada mahasiswa untuk meninjau ulang kata-kata baru yang telah dipelajarinya di dalam kelas.

\section{Portofolio Hasil Belajar}

Pada bagian ini disajikan ulasan terhadap portofolio hasil belajar mahasiswa yang terdiri dari: (1) flash cards; (2) posting kalimat; (3) rekaman berbicara; dan (4) menulis ringkasan.

\section{Flash Cards}

Flash cards dapat digunakan mahasiswa untuk mempelajari kembali perbendaharaan kata-kata baru dan mengekalkan ingatan mereka terhadap kata-kata tersebut. Ketika membuat flash cards, mahasiswa juga akan melakukan pengulangan belajar terhadap kata-kata yang dipelajari. Dalam perkuliahan BIK, mahasiswa diminta untuk membuat minimal 15 flash cards. Flash Cards dibuat dua sisi. Sisi bagian depan memuat nama mahasiswa, nomor induk mahasiswa, tema/bidang ilmu, kata dan jenis kata, serta sumber. Sisi belakang memuat arti kata dalam Bahasa Inggris, terjemahan arti dalam Bahasa Indonesia, contoh kalimat yang dikutip dari sumber, dan contoh kalimat yang dibuat oleh mahasiswa.

Mahasiswa diberi pilihan untuk membuat flash cards dalam bentuk fisik berupa kartu atau membuatnya dalam bentuk berkas elektronik. Untuk pembuatan flash cards dalam bentuk kartu, mahasiswa dapat menghias flash cards tersebut. Menanggapi kedua pilihan ini, sebagian besar mahasiswa $(85,37 \%)$ memilih untuk membuat flash cards berbentuk berkas elektronik, karena lebih mudah dan tidak memerlukan waktu yang lama untuk menghias. Tujuh mahasiswa $(8,53 \%)$ membuat flash cards ber- 
bentuk kartu, dua mahasiswa (2,44\%) membuat dua versi, dan tiga mahasiswa $(3,66 \%)$ tidak menyerahkan tugas ini. Mahasiswa yang membuat flash cards dalam dua versi teridentifikasi memang memiliki minat yang lebih tinggi terhadap mata kuliah BIK yang terbukti dengan tingginya intesitas mereka mengakses dan membuat postingan pada Edmodo. Mahasiswa ini juga aktif mengajukan pertanyaan melalui posel kepada instruktur.

Terhadap flash cards berbentuk kartu, instruktur utama memberikan saran dan komentar secara lisan kepada mahasiswa. Sedangkan flash cards berbentuk berkas elektronik dievaluasi menggunakan fitur track-change pada MsWord. Pertama, instruktur memperbaiki kesalahan terjemahan pada arti dalam Bahasa Indonesia dan kalimat yang ditulis oleh mahasiswa di dalam Bahasa Inggris. Komentar mengenai kekeliruan yang paling banyak ditemukan dan cara menghindari kekeliruan tersebut diberikan setelah flash cards terakhir dengan menggunakan komentar yang diterakan pada sebuah kotak berwarna kuning.

\section{Posting Kalimat}

Kegiatan menulis dan posting kalimat bertujuan untuk melatih kepekaan mahasiswa dalam mengenali struktur kalimat Bahasa Inggris. Sebelum diberi tugas menulis dan posting kalimat, mahasiswa diberi pelajaran mengenai kalimat sederhana, kalimat majemuk, dan kalimat kompleks. Mahasiswa kemudian dikelompokkan bertiga dalam satu kelompok untuk membuat kalimat dengan menggunakan lima kata yang ditentukan oleh instruktur. Pertama-tama, mahasiswa harus terlebih dahulu mencari arti kata tersebut dan mempelajari contoh kalimat dari kamus elektronik. Selanjutnya mahasiswa menulis kalimatnya dan memposting hasilnya pada Edmodo untuk diperbaiki oleh instruktur dan diberi komentar oleh mahasiswa lain. Mahasiswa kemudian mempelajari kalimat yang telah diperbaiki oleh instruktur dan pada pertemuan kelas mereka melakukan presentasi mengenai perbandingan antara kalimat yang mereka buat dengan perbaikan yang diberikan oleh instruktur.

Instruktur memperbaiki kalimat yang ditulis mahasiswa supaya sesuai dengan kaidah kebahasaan. Perbaikan terhadap kesalahan dilakukan dengan menggunakan huruf berwarna biru dan bagian yang diganti dari tulisan siswa diberi coretan. Koreksi terhadap aspek kebahasaan tidak hanya dilakukan pada kalimat Bahasa Inggris saja, karena ketidakjelasan dalam penerjemahan akibat struktur kalimat Bahasa Indonesia yang kurang baik juga dapat teridentifikasi dari sebagian besar hasil kerja mahasiswa. Setelah mengoreksi aspek kebahasaan, instruktur kemudian memberikan komentar dalam Bahasa Inggris. Mahasiswa diminta untuk mencoba memahami komentar tersebut dan terlebih dahulu menggunakan Google Translate untuk mengartikannya. Pada tahap selanjutnya, mahasiswa dapat merespon ulang komentar dengan mengirim posel kepada instruktur atau berdiskusi dengan instruktur di Edmodo.

\section{Rekaman Berbicara}

Rekaman pertama yang harus dibuat oleh mahasiswa adalah perkenalan diri dalam bentuk audio atau video pada VoiceThread. Langkah-langkah pembuatan VoiceThread dijelaskan melalui petunjuk yang diposting pada Edmodo. Kedua instruktur juga membuat contoh perkenalan diri masing-masing dan contoh tersebut disajikan pada pertemuan di kelas. Mengikuti petunjuk dan contoh tersebut, mahasiswa kemudian membuat postingan VoiceThread. Sebagian besar mahasiswa (91,47\%) membuat postingan berbentuk audio, tiga mahasiswa membuat video $(3,65 \%)$, dan empat mahasiswa (4,88\%) tidak menyelesaikan tugas ini. Membuat VoiceThread audio memang lebih mudah daripada video. Untuk membuat video mahasiswa perlu menggunakan webcam atau mengunggah foto-foto untuk dijadikan tayangan pada video. 
Pada sebuah video berdurasi 57 detik seorang mahasiswa terdengar sangat lancar berbicara, dapat mengemukakan idenya dengan jelas, dan memiliki kepercayaan diri yang sangat tinggi di dalam menggunakan Bahasa Inggris. Tampilan visual pada video menjadi atribut yang dapat membantu memperjelas maksud yang ingin disampaikan oleh mahasiswa ketika pengujarannya terdengar kurang jelas. Berikut ini adalah kutipan perkenalan diri yang disampaikan, "....in this occasion I will introduce myself. But, I can't speak English as well as possible. This is a special time to develop my English here. Ok, twenteen years ago, my parents have given me a special good name. Of course, this is mine. This is my name. It's MAI, but you can call me A. I am a librarian too at library of Darul Hikmah in Mojokerto. I am from history city in our country. Of course, it is Mojokerto..."

Meskipun masih terdapat kesalahan struktur kalimat, pemilihan padanan kata, tata bahasa, dan kekeliruan pengujaran, tampilan visual pada video dapat digunakan untuk memperjelas maksud mahasiswa tersebut. Pada video, mahasiswa juga membuat halaman pembuka yang mencantumkan identitas kampus. Ia juga menggunakan foto-foto gedung kuliah untuk memperjelas status dirinya sebagai mahasiswa UM. Mahasiswa ini juga menyajikan beberapa foto yang merupakan bagian dari sejarah dan keunikan kota kelahirannya. Selain menggunakan foto diri, mahasiswa menggunakan foto bersama teman dan juga foto-foto dirinya ketika mengikuti kegiatan di dalam maupun di luar kampus untuk menampilkan identitas dirinya.

Selain membuat rekaman perkenalan diri, mahasiswa juga diwajibkan untuk membuat rekaman latihan pelafalan kata. Ada 10 kata yang ditugaskan di dalam rekaman ini, yaitu: constitution, declare, justice, solicitor, democracy, parliament, defence, victim, society, dan government. Dalam pertemuan di kelas, instruktur mem-berikan contoh penggunaan kamus elek-tronik dan iM-Transalator untuk men-dengarkan pengujaran kata-kata tersebut. Selanjutnya, mahasiswa diminta untuk me-lakukan praktik mengucapkan secara nya-ring katakata tersebut. Setelah pertemuan kelas, mahasiswa diwajibkan untuk berlatih sendiri dan menggunakan kamus elektronik maupun iM-Translator untuk melakukan pengecekan terhadap kebenaran ujarannya dan kemudian merekam ujarannya.

Berdasarkan hasil evaluasi terhadap sebagian besar rekaman mahasiswa, pada umumnya mahasiswa mencoba melakukan pengujaran dengan baik, namun pengaruh aksen terutama kesamaan beberapa kata tersebut dengan kata-kata di dalam Bahasa Indonesia sangat mempengaruhi kualitas ujaran yang dihasilkan. Ujaran mahasiswa yang sangat dipengaruhi oleh pengujaran dalam Bahasa Indonesia, terutama pada kata constitution, democracy, dan parliament. Sedangkan kekeliruan di dalam mem-berikan penekanan suku kata teridentifikasi pada kata declare, justice, democracy, defence, dan society.

\section{Menulis Ringkasan}

Menulis ringkasan setelah mendengarkan rekaman video presentasi dari TedTalk merupakan tugas yang oleh mahasiswa diangap paling sulit untuk diselesaikan. Kendala utama di dalam membuat ringkasan tersebut adalah kemampuan mendengarkan dan penguasaan kosa kata yang masih kurang. Pada awal kegiatan, mahasiswa hanya diberikan video dan diminta untuk membuat ringkasan dan intisari dari pembicaraan. Pada tahap kedua, mahasiswa diminta untuk mendengarkan kembali video sambil membaca transkripsi dari video tersebut. Menurut mahasiswa, mendengarkan sambil membaca transkripsi membuat mereka lebih mengerti isi pembicaraan pada video dan membuat kata-kata yang kurang jelas menjadi jelas, namun kendala ketidakmengertian terhadap arti dari begitu banyak kata baru masih tetap membuat mereka kesulitan untuk menulis ringkasan. 
Mahasiswa belum dapat membuat ringkasan tanpa menghindari pencuplikan langsung dari isi transkripsi. Kalimatkalimat yang ditulis belum membentuk koherensi sebuah paragraf. Kesalahan tipografi pengetikan kata ditemukan cukup banyak dan pada hampir semua tugas yang diserahkan. Evaluasi terhadap ringkasan hanya dilakukan dalam bentuk komentar secara umum terhadap kesalahan teknik kebahasaan dan belum dilakukan pengoreksian secara rinci terhadap koherensi tulisan. Dasar pertimbangan kedua instruktur terhadap evaluasi ini adalah, mata kuliah BIK bukan merupakan mata kuliah menulis Bahasa Inggris dan kemampuan menulis ringkasan dan paragraf, karena hal tersbut memerlukan latihan khusus dan jangka waktu yang lebih panjang dari sekedar hanya dua kali pertemuan kuliah pada BIK. Setidaknya kegiatan latihan menulis di BIK telah memperkenalkan aspek kebahasaan yang juga cukup penting di dalam penerapan Inggris ke bidang Kewarganegaraan, yakni menulis dan meringkas pembicaraan sesuai dengan bidang ilmu yang dipelajari.

\section{Nilai Akhir dan Evaluasi Mahasiswa}

Secara keseluruhan perolehan nilai mahasiswa lebih dari 50\% berada pada kategori sangat baik. Mahasiswa dapat memperoleh nilai sangat baik dan baik karena dapat melengkapi portofolio kegiatan yang berbobot $50 \%$ dari seluruh total nilai dengan dan juga mencapai hasil ujian di atas $60 \%$ benar. Portofolio yang dikerjakan dengan serius terbukti mampu mem-bantu mahasiswa dalam mengerjakan soal-soal ujian tengah semester dan ujian akhir. Mahasiswa yang memperoleh nilai cukup dan kurang teridentifikasi tidak melengkapi portofolio yang diwajibkan dan sering tidak hadir kuliah, sehingga tidak memiliki informasi yang cukup untuk mengerjakan soal-soal ujian.

Jika dibandingkan antara kelas C dan kelas $\mathrm{D}$, terlihat dengan jelas bahwa perolehan nilai kelas $\mathrm{C}$ lebih dominan ke kategori sangat baik, sementara kelas D lebih ke kategori baik dan cukup (lihat table 1). Meskipun memiliki tingkat keaktifan dan motivasi yang sama di dalam kelas, mahasiswa kelas $C$ lebih aktif mengunjungi Edmodo dan menghasilkan portofolio dengan kualitas yang lebih baik dibandingkan dengan kelas D.

Tabel 1. Nilai Akhir Mahasiswa

\begin{tabular}{lccc}
\hline $\begin{array}{c}\text { Kategori dan } \\
\text { Nilai }\end{array}$ & $\begin{array}{c}\text { Jumlah } \\
\text { Maha- } \\
\text { siswa } \\
\text { Kelas C }\end{array}$ & $\begin{array}{c}\text { Jumlah } \\
\text { Maha- } \\
\text { siswa } \\
\text { Kelas D }\end{array}$ & $\begin{array}{c}\text { Jumlah } \\
\text { Maha- } \\
\text { siswa } \\
\text { Kelas C } \\
\& \text { D }\end{array}$ \\
\hline Sangat Baik & 27 & 16 & 43 \\
(A) & $(62,79 \%)$ & $(41,03 \%)$ & $(52,44 \%)$ \\
Baik & 9 & 14 & 23 \\
(A-,B+,\& B) & $(20,93 \%)$ & $(35,90 \%)$ & $(28,05 \%)$ \\
Cukup & 3 & 8 & 11 \\
(B-,C+, \&C) & $(6,98 \%)$ & $(20,51 \%)$ & $(13,41 \%)$ \\
Kurang & 4 & 1 & 5 \\
(C-, D, \& E) & $(9,30 \%)$ & $(2,56 \%)$ & $(6,10 \%)$ \\
\hline
\end{tabular}

Evaluasi mahasiswa dilakukan terhadap mata kuliah dengan mengisi kuisioner yang disertakan pada soal ujian akhir. Pada bagian ini akan disajikan evaluasi mahasiswa terhadap lima pertanyaan kuesioner yang berhubungan dengan tujuan penelitian ini. Terhadap lima aspek dalam perkuliahan ini menunjukkan mahasiswa memberikan evaluasi positif, di mana antara $80 \%-90 \%$ menyatakan setuju dan sangat setuju terhadap pernyataan yang diajukan (lihat Tabel 2). Pernyataan yang diajukan untuk dievaluasi mahasiswa adalah: (1) materi-materi yang disajikan memberikan manfaat bagi mahasiswa, (2) organisasi perkuliahan membantu mahasiswa dalam belajar, (3) tugas-tugas yang diberikan membantu mahasiswa untuk belajar, (4) kegiatan perkuliahan menekankan pada proses belajar siswa aktif, dan (5) dosen memperhatikan proses belajar mahasiswa.

Salah satu kekhawatiran instruktur ketika merancang perkuliahan ini adalah mahasiswa akan merasa terbebani dengan banyaknya tugas dan kegiatan yang harus diselesaikan baik di dalam maupun di luar kelas. Jika dicermati dengan seksama, ma- 
sih terdapat sekitar 20\% mahasiswa yang merasa terbebani oleh tugas. Namun secara keseluruhan sebagian besar mahasiswa dapat menjalankan tugas tersebut tanpa merasa terbebani. Mahasiswa justru merasakan manfaat dari melakukan kegiatan tersebut dan memperoleh nilai guna dari mempelajari atau melaksanakan kegiatan tersebut.

Tabel 2. Evaluasi Mahasiswa terhadap BIK

\begin{tabular}{|c|c|c|c|c|c|}
\hline No. & $\begin{array}{l}\text { Topik } \\
\text { Evaluasi }\end{array}$ & $\begin{array}{l}\text { Sangat } \\
\text { Setuju }\end{array}$ & Setuju & $\begin{array}{l}\text { Kurang } \\
\text { Setuju }\end{array}$ & $\begin{array}{l}\text { Tidak } \\
\text { Setuju }\end{array}$ \\
\hline 1. & $\begin{array}{l}\text { Materi-materi } \\
\text { yang } \\
\text { disajikan } \\
\text { memberikan } \\
\text { manfaat bagi } \\
\text { maha-siswa }\end{array}$ & $\begin{array}{c}41 \\
(50 \%)\end{array}$ & $\begin{array}{c}34 \\
(41,7 \%)\end{array}$ & $\begin{array}{c}2 \\
(2,4 \%)\end{array}$ & $\begin{array}{c}5 \\
(6,1 \%)\end{array}$ \\
\hline 2. & $\begin{array}{l}\text { Organisasi } \\
\text { perkuliahan } \\
\text { membantu } \\
\text { mahasiswa } \\
\text { dalam belajar }\end{array}$ & $\begin{array}{c}35 \\
(42,7 \%)\end{array}$ & $\begin{array}{c}43 \\
(52,4 \%)\end{array}$ & $\begin{array}{c}1 \\
(1,22 \%)\end{array}$ & $\begin{array}{c}3 \\
(3,7 \%)\end{array}$ \\
\hline 3. & $\begin{array}{l}\text { Tugas-tugas } \\
\text { yang } \\
\text { diberikan } \\
\text { membantu } \\
\text { mahasiswa } \\
\text { untuk belajar }\end{array}$ & $\begin{array}{c}28 \\
(34,1 \%)\end{array}$ & $\begin{array}{c}38 \\
(46,3 \%)\end{array}$ & $\begin{array}{c}11 \\
(13,4 \%)\end{array}$ & $\begin{array}{c}5 \\
(6,1 \%)\end{array}$ \\
\hline 4. & $\begin{array}{l}\text { Kegiatan } \\
\text { perkuliahan } \\
\text { menekan } \\
\text { belajar aktif }\end{array}$ & $\begin{array}{c}42 \\
(51,2 \%)\end{array}$ & $\begin{array}{c}37 \\
(45,1 \%)\end{array}$ & $\begin{array}{c}0 \\
(0,0 \%)\end{array}$ & $\begin{array}{c}3 \\
(3,7 \%)\end{array}$ \\
\hline 5. & $\begin{array}{l}\text { Dosen } \\
\text { memperhatik } \\
\text { an proses } \\
\text { belajar } \\
\text { mahasiswa }\end{array}$ & $\begin{array}{c}51 \\
(62,2 \%)\end{array}$ & $\begin{array}{c}27 \\
(32,9 \%)\end{array}$ & $\begin{array}{c}4 \\
(4,9 \%)\end{array}$ & $\begin{array}{c}0 \\
(0,0 \%)\end{array}$ \\
\hline
\end{tabular}

Lebih dari 50\% mahasiswa merasakan manfaat dari porsi kegiatan yang lebih banyak diberikan kepada mahasiswa di dalam menjalankan aktifivas di kelas. Mereka merasa lebih memiliki kemampuan untuk saling membantu satu sama lain di dalam menyelesaikan tugas. Kegiatan mengunjungi dan menyelesaikan tugas di Edmodo, teridentifikasi juga menjadi salah satu indikator yang membuat mahasiswa berpendapat bahwa mereka memiliki peranan lebih aktif karena dalam diskusi mereka dapat membantu instruktur untuk men- jawab pertanyaan-pertanyaan yang diajukan oleh teman-temannya.

Komentar dan koreksi yang diberikan terhadap tugas yang diberikan dinilai oleh mahasiswa sebagai suatu bentuk perhatian dosen terhadap kegiatan dan proses belajar mereka. Sebagian besar mahasiswa, mencapai lebih dari $60 \%$, menilai kedua instruktur telah berusaha memberikan perhatian yang cukup maksimal dalam membantu mereka di dalam belajar. Meskipun mahasiswa merasa belum dapat mencapai hasil belajar secara optimal seperti yang diharapkan oleh instruktur, namun mereka merasakan manfaat dari komentar serta evaluasi yang diberikan untuk membantu mereka dalam belajar dan memahami Bahasa Inggris.

\section{Pembahasan}

Penilaian proses dan aktivitas kelas berpusat pada mahasiswa yang diterapkan pada kuliah BIK sesuai dengan pendekatan komunikatif dalam pembelajaran bahasa kedua (Ju, 2013, p. 1581; Candlin \& Mercer, 2001, p. 155; Klapper, 2006, p. 109). Mahasiswa dapat berperan aktif di kelas dan di Edmodo dengan menggunakan berbagai metode komunikasi untuk berinteraksi dengan media, konten belajar, sesama mahasiswa, dan dengan instruktur (Moore, 2009, pp. 1-7). Dalam proses interaksi dan komunikasi belajar, instruktur menjalankan tugas sebagai mediator dan fasilitator belajar dengan memberikan arahan, saran, dan koreksi terhadap kekurangan mahasiswa dalam penyelesaian kegiatan belajar. Instruktur melakukan mediasi dan mengusahakan lingkungan belajar serta proses belajar dapat membantu mahasiswa melihat dengan jelas dan dapat mencapat tujuan belajar. Sesuai dengan teori perubahan dan juga konsep ZPD (Vygotsky, 1967 , p. 16), pembelajaran dengan pendekatan aktif pada mata kuliah ini telah membuka kesempatan bagi mahasiswa untuk melampaui tahap arahan dan bimbingan ke tahap mampu secara mandiri untuk terus dapat mengembangkan ke- 
mampuan belajar dalam memanfaatkan media yang tersedia.

Ruang kelas dan Edmodo telah dirancang oleh instruktur untuk memungkinkan mahasiswa memperoleh kemudahan dan rasa bisa (affordances) untuk menyelesaikan tugas yang diberikan (Barnett, 2011, p. 141; Yang, 2018, p. 27). Dalam merancang lingkungan belajar, instruktur telah mengintegrasikan atributatribut belajar sesuai dengan prinsip perancangan lingkungan belajar yang disyaratkan dalam pendekatan ekologi. Lingkungan belajar tersebut memberi kesempatan seluasnya bagi mahasiswa untuk mengetahui dan menggunakan teknologi digital yang tersedia dengan bebas di laman-laman internet dan di sekitar tempat belajar siswa dalam pencapaian bahsil belajar optimal (Barnett, 2011, p. 141; Yang, 2018, p. 27). Ruang kelas telah disetting oleh instruktur dengan mengadakan telekonferensi dan berbagai media yang tersedia di internet juga diperkenalkan kepada mahasiswa. Selain mempelajari bahasa, mahasiswa juga diperkenalkan dengan berbagai teknologi baru yang dapat digunakan oleh dirinya sendiri untuk mengembangkan proses belajar bahasa atau proses belajar ilmu lainnya secara mandiri. Proses belajar seperti ini selaras dengan teori pengembangan lingkungan belajar multimodal dan juga sesuai dengan konsepsi pembelajaran menggunakan media/teknologi yang mutakhir (Farias, Obilinovic, \& Orrego, 2007, pp. 178-180).

Pada perkuliahan BIK, kolaborasi antar-instruktur dan kolaborasi instruktur dengan mahasiswa merupakan kunci utama keberhasilan pelaksanaannya (Hanusch, Obijiofor \& Volcic, 2009, p. 72; Stark, 2015, p. 7). Instruksional yang jelas mempermudah pengalihan informasi kepada mahasiswa. Instruksional yang jelas dapat dilakukan dengan adanya rancangan instruksional yang telah disesuaikan dengan kebutuhan mahasiswa. Kedua instruktur merasakan manfaat dari analisis kebutuhan (Dick, Carey \& Carey, 2014, pp.
16-24) dan penerapan metode perancangan instruksional terhadap kelancaran di dalam proses pencapaian tujuan belajar. Selain itu, motivasi belajar mahasiswa yang juga cukup tinggi mempermudah kolaborasi antara instruktur dengan pembelajar dalam membantu mereka mencapai hasil belajar yang diharapkan.

Penggunaan media belajar daring telah terbukti dalam banyak penelitian mampu menghasilkan peningkatan kemampuan belajar (Klopfer et al., 2009, p. 3; Umeh \& Nsofor, 2014, pp. 74-75). Meskipun belum secara langsung penelitian ini mengevaluasi efektivitas dari setiap media belajar, namun dapat terlihat dengan jelas mahasiswa berusaha memanfaatkan media tersebut untuk menyelesaikan tugas yang dibebankan. Ketika menemui kesulitan, mahasiswa juga kembali ke lingkungan dari media tersebut untuk memperoleh bantuan dari teman atau dari instruktur. Media belajar daring tersebut terbukti sangat efektif untuk mengatasi perbedaan keberadaan lokasi geografis antara instruktur tamu dengan mahasiswa. Meskipun tidak berada di lokasi yang sama, mahasiswa tetap dapat berinteraksi dengan instruktur tamu dan memperoleh bantuan dalam penyelesaian masalah belajarnya.

Pelaksanaan blended learning dapat dengan jelas terlihat dari perpaduan kegiatan instruksional, strategi instruksional, dan interaksi mahasiswa dengan instruktur (Garrison \& Kanuka, 2004, p. 97). Sebagian besar evaluasi terhadap hasil belajar mahasiswa dapat dilakukan secara bersama antara instruktur utama dan instruktur tamu karena keduanya sebagai moderator dapat mengakses hasil kegiatan mahasiswa yang diserahkan melalui Edmodo. Edmodo telah menjadi laman manajemen sistem belajar yang sangat efektif meskipun memang tidak semua fitur yang tersedia memberikan kemudahan bagi instruktur dan mahasiswa untuk berinteraksi. Kehadiran instruktur tamu dengan menggunakan media telekonferensi juga menunjukkan suatu upaya institusi mendatangkan sumber belajar dari luar universitas dalam 
rangka memperoleh hasil yang lebih optimal untuk proses belajar mahasiswa (KemalRamani, et. al., 2018, pp. 5-35).

\section{Simpulan}

Pelaksanaan blended learning memer-lukan kolaborasi antar instruktur karena pengembangan mekanisme dan sistem belajar pada kuliah blended learning tidak sama dengan pembelajaran pada perkuliahan tradisional. Pelaksanaan coteaching mata kuliah blended learning menjadi sangat penting karena selain diperlukan keahlian dalam mengajar, instruktur juga perlu menguasai cara perancangan instruksional yang tepat, sehingga dapat mengintegrasikan atribut-atribut belajar yang dapat meningkatkan kualitas lingkungan belajar.

Pengembangan dan pelaksanaan blended learning BIK di UM menunjukkan proses kolaborasi untuk menghasilkan instruksional yang efektif memerlukan waktu yang cukup lama. Program blended learning BIK secara co-teaching dapat dilaksanakan meskipun belum sempurna. Pada perkuliahan ini, kedua instruktur dan mahasiswa dapat saling mendukung untuk mencapai tujuan belajar yang ditetapkan dalam rancangan instruksional.

\section{Daftar Pustaka}

Adzharuddin, N. A., \& Ling, L.H. (2013). Learning Management System (LMS) among University Students: Does it work?. International Journal of eEducation, e-Management and eLearning, 3(3), 248-252. doi:https:// doi.org/10.7763/IJEEEE.2 013.V3.233.

Barnett, R. (2011). Being a University. Oxon: Routledge.

Basta, J. (2011). The role of the communicative approach and cooperative learning in higher education. Linguistic and Literaturee, 9(2), 125-143.
Bronfenbrenner, U. (1979). The ecology of human development: experiments by nature and design. Cambridge, Massachusetts: Harvard University Press.

Bronfenbrenner, U. (1994). Ecological models of human development. In International Encyclopedia of Education, Vol. 3, 2nd edition. Oxford: Elsevier.

Candlin, C. N., \& Mercer, N. (Eds.). (2001). English language teaching in its social context: a reader. Abingdon: Routledge.

Creswell, J. W. (2014). Research design qualitative, quantitative, and mixed methods approached, $4^{\text {th }}$ edition. Los Angeles: Sage.

Dick, W., Carey, L., \& Carey, J. O. (2014). The systematic design of instruction, $8^{\text {th }}$ edition. Boston: Allyn and Bacon.

Drothler, R. (2002). 50 activities to promote language learning.

https:/ / www.advantagespeech.com/ resources/Activities \% 20to \%20Promot e\%20Language\%20Learning.pdf (diakses 14 Mei 2018).

El-Mowafy, A., Kuhn, M., \& Snow, T. (2013). Blended learning in higher education: current and future challenges in surveying education. Educational Research, 23(2), 132-150.

Farias, M., Obilinovic, K., Orrego, R. (2007). Implications of multimodal learning models for foreign language teaching and learning. USA: Colombian Applied Linguistics.

Friend, M. (2008). Co-teaching: principles, practices and pragmatics. Greensboro, NC: Marilyn Friend, Inc.

Friend, M. (2016). Co-teaching: Creating Success for ALL Learners. Supplemental Materials for the Workshop Council for Exceptional Children and the San Mateo County Office of Education. Wisconsin: Marilyn Friend, Inc.

Garrison, D. R., \& Kanuka, H. (2004). Blended learning: uncovering its 
transformative potential in higher education. Internet and Higher

Education, 7(2), 95-105.

doi:https://doi.org/10.1016/j.iheduc. 2004.02.001.

Gibson, J. J. (1979). The ecological approach to visual perception. Psychology Press.

Hamdan, A. R., Anuar, M. K., \& Khan, A. (2016). Implementation of co-teaching approach in an inclusive classroom: overview of the challenges, readiness, and role of special education teacher. Asia Pacific Education Review, 17(2), 289-298.

doi:https:// doi.org/10.1007/s12564016-9419-8.

Hanusch, F., Obijiofor, L., \& Volvic, Z. (2009). Theoretical and practical issues in team-teaching a large undergraduate class. International Journal of Teaching and Learning in Higher Education, 21(1), 66-74.

Harkonen, U. (2007). The Bronfenbrenner Ecological System Theory of Human Development. International Conference Person Color Nature Music. Daugavpils University, Saule, Latvia. 1- 19.

Ju, F. (2013). Communicative Language teaching (CLT): A critical and Comparative Perspective. Theory and Practice in Language Studies, 3(9), 15791583. doi:https:// doi.org/10.4304/tpls.3.9.1 579-1583.

KemalRamani, A., Zhang, J., Wang, X., Rathbun, A., Corcoran, L., \& Diliberti, M., (2018). Student Access to Digital Learning Resources Outside of the Classroom. National Center for Education Statistics Report.

Klapper, J. (2006). Understanding and developing good practice: language teaching in higher education. London: CILT.

Klopfer, E., Osterweil, S., Groff, J., \& Haas, J. (2009). Using the Technology of Today in the Classroom Today: the Instructional Power of Digital Games, Social Networking Simulations and How teachers can Leverage Them.

Massachusetts: The Education Arcade Massachusetts Institute of Technology.

Liu, I. C., \& Sayer, P. (2016). Reconciling pedagogical beliefs and teaching practices: chinese teachers and the pressures of a U.S. High School foreign language context. The Journal of Language Teaching and Learning, 6(1), 1-19.

Moore, M. G. (2009) Editorial: three types of interaction. American Journal of Distance Education, 3(2), 1-7. doi:https:// doi.org/10.1080/08923648 909526659.

Okeke, F. N. (2013). Management of facilities in the classroom. Journal of Emerging Trends in Educational Research and Policy Studies, 4(1), 100-104.

Rosenshine, B., \& Meister, C. (1992). The use of scaffolds for teaching in higherlevel cognitive strategies. Educational Leadership, 49(7), 26-33.

Sejzi, A. A., \& Aris, B. (2013, October). Learning Management System (LMS) and Learning Content Management System (LCMS) at Virtual University. The 2nd International Seminar on Quality and Affordable Education. Johor Bahru, Johor, Malaysia.

Sheerman, B. (2010). Transforming education outside the classroom. London: House of Commons - The Stationery Office Limited.

Shyamlee, S.D., \& Phil, M. (2012). Use of technology in english language teaching and learning: an analysis. International Conference on Language, Medias and Culture, 33, 150 -156.

Stark, E. (2015). Co-teaching: the benefits and disadvantages. Journal on Best Teaching Practices, 2(2), 7-8. 
Texas Education Agency. (2010). Coteaching: guideline for co-teaching in Texas. Texas: Texas Education Agency.

https:// projects.esc20.net/upload/pa ge/0102/docs/CoTeachingAccessible. pdf (diakses 14 Mei 2018).

The Herridge Group. (2004). The use of traditional instructional systems design models for e-learning. http://www.herridgegroup.com/pdf s/The \%20use \%20of \%20Traditional $\% 2$ 0ISD \% 20for\%20eLearning.pdf (diakses 12 Mei 2018).
Umeh, A. E., \& Nsofor, C.C. (2014). Modern trends in the use of educational technology in the classroom. International Journal of Education Learning and Development, 2(5), 73-74.

Vygotsky, L. S. (1967). Play and its role in the mental development of the child. Soviet Psychology, 5(3), 6-18.

Yang, J. (2018). On teachers' role in CALLan ecological language perspective. US-China Foreign Language, 16(1), 2529.

doi:https://doi.org/10.17265/15398080/2018.01.002. 